BAKTIMAS

Jurnal Pengabdian pada Masyarakat
Vol. 1, No. 2,

Agustus 2019
eISSN 2685-113x

pISSN 2685-0303

\title{
Pemberdayaan Masyarakat Kelompok Tani melalui Teknologi Pembuatan Pupuk Kascing
}

\author{
Maisura, Ainol Mardhiah, Nur Hafni \\ Fakultas Pertanian Universitas Malikussaleh \\ maisuraali@ymail.com
}

\begin{abstract}
Abstrak
Permasalahan yang dihadapi Mitra adalah masih berkurangnya pasokan pupuk an organik, serta distribusi kurang lancar dan harga di tingkat petani sering melampaui harga eceran tertinggi (HET) yang ditetapkan pemerintah. Pengurangan dan penghapusan subsidi harga pupuk membuka peluang besar untuk menggunakan pupuk organik. Kascing merupakan salah satu pupuk organik yang memiliki unsur hara yang lengkap dan dapat menjadi sumber hara untuk pertumbuhan tanaman. Pembuatan pupuk kascing ini sangat dimungkinkan karena berlimpahnya bahan baku untuk pembuatan pupuk kascing di daerah mitra. Kegiatan ini bertujuan untuk meningkatkan pemanfaatan sumberdaya alam lokal, mengurangi penggunaan pupuk anorganik, peningkatan pendapatan dan kesejahteraan mitra. Metode pelaksanaan kegiatan serta solusi yang ditawarkan yaitu memberikan penyuluhan dan pelatihan tentang pemanfaatan sumberdaya lokal (cacing) dan limbah pertanian (pupuk kandang sapi), cara pembuatan pupuk kascing, dan memproduksi pupuk kascing. Kegiatan selanjutnya melakukan aplikasi langsung dilapangan yaitu melalui pembuatan danplot (plot percontohan). Hasil yang dicapai dari kegiatan ini adalah Setelah melaksanakan kegiatan penyuluhan dan pelatihan pembuatan pupuk kascing, petani telah mengetahui bagaimana memanfaatkan pupuk kandang sapi untuk membuat pupuk kascing, Petani yang menanam sayuran sudah memanfaatkan pupuk kandang sapi sebagai bahan baku lokal untuk membuat pupuk kascing dan bertambahnya pengetahuan tentang manfaat cacing Setelah mengikuti penyuluhan dan pelatihan pembuatan pupuk kascing, petani sudah bisa memproduksi pupuk kascing

Kata kunci : kascing, kelompok tani, pupuk organik
\end{abstract}

\section{PENDAHULUAN}

Kelompok tani Sejati I dan Beusare I yang berada di desa Paloh Punti sudah menunjukan dukungan terhadap gerakan untuk menuju pertanian non-kimia. Pupuk Kascing sudah dikenal sebagai cara terbaik untuk penyuburan tanah dan tanaman yang sehat. Berdasarkan fenomena tersebut, maka ketersediaan pupuk menjadi isu yang cukup penting di Aceh. Sebab sektor pertanian begitu dominan dan sangat besar peranannya bagi pembangunan ekonomi daerah. Hal itu terbukti, dari tahun ke tahun tingkat pertumbuhan ekonomi Aceh dari sektor pertanian terus meningkat, bahkan pertanian menjadi penopang ekonomi paling kuat saat ini. Sehingga Pertumbuhan pertanian tidak bisa dilepaskan dengan tingkat kebutuhan terhadap pupuk, Untuk itu 
BAKTIMAS

Jurnal Pengabdian pada Masyarakat
Vol. 1, No. 2,

Agustus 2019
eISSN 2685-113x

pISSN 2685-0303

diperlukan proses pembuatan pupuk tanpa melibatkan gas bumi, maka alternatif yang paling tepat yaitu dengan menggunakan pupuk organik.

Pupuk organik sebagian besar atau seluruhnya terdiri atas bahan organik yang berasal dari tanaman dan atau hewan yang telah melalui proses rekayasa, dapat berbentuk padat atau cair yang digunakan untuk mensuplai bahan organik untuk memperbaiki sifat fisik, kimia, dan biologi tanah. Pupuk organik sangat bermanfaat bagi peningkatan produksi pertanian baik kualitas maupun kuantitas, mengurangi pencemaran lingkungan, dan meningkatkan kualitas lahan secara berkelanjutan. Kascing merupakan salah satu pupuk organik yang memiliki unsur hara yang lengkap dan dapat sangat bermanfaat bagi pertumbuhan tanaman. Kandungan Kascing sangat tergantung dengan bahan organik dan jenis cacing yang dipakai sebagai pengurai. Namun pada umumnya, pupuk Kascing mempunyai unsur hara yang dibutuhkan tanaman seperti nitrogen, fosfor, mineral dan vitamin. Dengan kandungan unsur hara ini, maka kascing sangat layak untuk digunakan sebagai pupuk (Simanunglangit et al, 2006).

Gampong Paloh Punti merupakan salah satu desa yang berada di Kecamatan Muara Satu Lhokseumawe, sebagian besar lahan dipergunakan untuk lahan pertanian dan peternakan terutama peternakan sapi. Melihat potensi tersebut maka Gampong Paloh Punti sangat cocok untuk dikembangkan untuk menjadi gampong untuk memproduksi pupuk organik kascing melalui pengolahan kotoran sapi untuk dijadikan pupuk organik. Pupuk kotoran sapi mempunyai kandungan N, P dan K yang tinggi sehingga dapat mensuplai unsur hara yang dibutuhkan tanaman dan untuk memperbaiki struktur tanah menjadi lebih baik.

Banyaknya lahan-lahan pertanian yang belum dimanfaatkan secara optimal. Dari hasil survey kepada petani langsung, menyebutkan bahwa pengembangan usaha tani sering terkendala akibat dari tidak adanya atau kurangnya modal untuk usaha tani, terutama harga-harga input yang sangat mahal diantaranya adalah pupuk. Melihat potensi dari desa paloh punti yang cukup banyak tersedia bahan baku untuk pembuatan kascing yaitu pupuk kandang. Hampir semua lahan yang digunakan untuk usaha tani di Desa Paloh Punti masih mengandalkan penggunaan pupuk an organik.

Persoalan yang dihadapi Mitra adalah masih berkurangnya pasokan pupuk an organik, serta distribusi kurang lancar dan harga di tingkat petani sering melampaui harga eceran tertinggi (HET) yang ditetapkan pemerintah, dengan dibatasinya pasokan pupuk subsidi ini, maka pupuk kascing menjadi salah satu alternatif untuk mencukupi kebutuhan pupuk, hal ini dimungkinkan karena berlimpahnya bahan baku untuk pembuatan pupuk kascing tersebut.

\section{METODE PELAKSANAAN}

Pendekatan yang ditawarkan untuk menyelesaikan permasalahan yang dihadapi oleh Mitra dalam kegiatan ini adalah dengan metode sebagai berikut :

1. Metode ceramah dengan memberikan penyuluhan tentang cara beternak cacing dan teknik pembuatan pupuk kascing. 
Maisura, Ainol Mardhiah, Nur Hafni

2. Metode pelatihan aplikasi dilapangan yang meliputi Pembuatan tempat beternak cacing sekaligus tempat untuk membuat pupuk kascing.

3. Metode diskusi untuk memberikan kesempatan tanya jawab tentang hal-hal yang belum diketahui oleh petani tentang kascing

\section{Pelaksanaan Kegiatan}

Kegiatan ini disusun agar tepat sasaran dan sesuai dengan metode pendekatan yang digunakan yang disepakati dengan mitra adalah:

1. Memberikan ceramah tentang pemanfaatan bahan baku lokal berupa pupuk kandang untuk dapat dijadikan pupuk kascing

2. Membuat bangunan untuk beternak cacing dan tempat pembuatan pupuk kascing

3. Membuat kebun percontohan terutama untuk tanaman sayuran (Sawi)dan pangan (jagung dan kedelai) untuk aplikasi pupuk kascing

4. Pengemasan produk pupuk kascing

\section{Bentuk Materi Kegiatan}

Kegiatan yang dilakukan dalam bentuk penyuluhan, Pembuatan pupuk kascing dan pembuatan danplot atau kebun percontohan. Adapun materi yang diberikan antara lain :

1. Penyuluhan tentang cara beternak cacing dan pemanfaatan pupuk kandang sebagai bahan baku untuk membuat pupuk kascing

2. Teknik pembuatan pupuk kascing meliputi alat dan bahan-bahan yang dibutuhkan untuk pembuatan pupuk kascing serta cara aplikasi dan dosis pupuk kascing

3. Demonstrasi dengan cara membuat plot percontohan untuk aplikasi pupuk kascing terhadap tanaman sayuran dan pangan

\section{Kontribusi partisipasi mitra}

Dalam kegiatan ini mitra memberikan kontribusi dalam hal memberikan data profil mitra. Adapun keikutsertaan mitra dalam pelaksanaan program ini adalah :

1. Mengikuti penyuluhan dan pembinaan cara beternak cacing melalui pemberian pakan yang berasal dari limbah peternakan

2. Mengikuti penyuluhan dan pembinaan pembuatan pupuk kascing yang menggunakan limbah peternakan (pupuk kandang sapi)

3. Menyediakan bahan baku untuk pembuatan pupuk kascing yaitu limbah pupuk kandang dan cacing tanah.

4. Menyediakan lahan untuk tempat beternak cacing, pembuatan pupuk kascing dan lahan untuk budidaya sayur-sayuran

\section{HASIL DAN PEMBAHASAN}

Perkembangan ekonomi masyarakat di Kelurahan Paloh Punti ditopang oleh pertanian, perdagangan, dan home industri. Produktivitas dan akses penting didukung oleh bidang pertanian, seperti pertanian pepaya madu, persawahan dan pertanian 
BAKTIMAS

Jurnal Pengabdian pada Masyarakat
Vol. 1, No. 2,

Agustus 2019
eISSN 2685-113x

pISSN 2685-0303

tanaman sayuran lainnya. Kondisi sosial masyarakat di Gampong Paloh Punti berjalan normal di mana kegiatan-kegiatan kemasyarakatan berjalan dengan baik, namun kondisi perkampungan penduduk masih belum tertata di mana perkampungan tidak teratur dan masih banyak lahan-lahan kosong yang pemamfaatanya belum begitu maksimal.

Penggunaan lahan di Gampong Paloh Punti, sebagian besar dipergunakan untuk lahan pertanian dan peternakan terutama peternakan sapi. Melihat potensi tersebut maka Gampong Paloh Punti sangat cocok untuk dikembangkan untuk menjadi gampong untuk memproduksi pupuk organik kascing melalui pengolahan kotoran sapi untuk dijadikan pupuk organik terutama pupuk kascing.

Pengabdian melalui program IbM pemberdayaan masyarakat kelompok tani melalui teknologi pembuatan pupuk kascing telah dilaksanakan sejak bulan Mei 2016. Secara garis besar setelah dilakukan kegiatan pengabdian terjadi beberapa perubahan perilaku dan persepsi petani terhadap cacing. Cacing yang selama ini merupakan hewan yang menjijikkan ternyata membawa manfaat yang besar jika kita manfaatkan dengan tepat. Begitu juga dengan pupuk kandang yang selama ini kurang dimanfaatkan oleh petani sebagai pupuk organik. Selama ini petani hanya mengandalkan penggunaan pupuk anorganik yang justru dapat merusak tanah dan biota tanah. Kascing merupakan salah satu pupuk organik yang memiliki unsur hara yang lengkap dan dapat menjadi sumber hara untuk pertumbuhan tanaman. Berikut teknologi pembuatan pupuk kascing yang telah diterapkan di Gampong Paloh Punti.
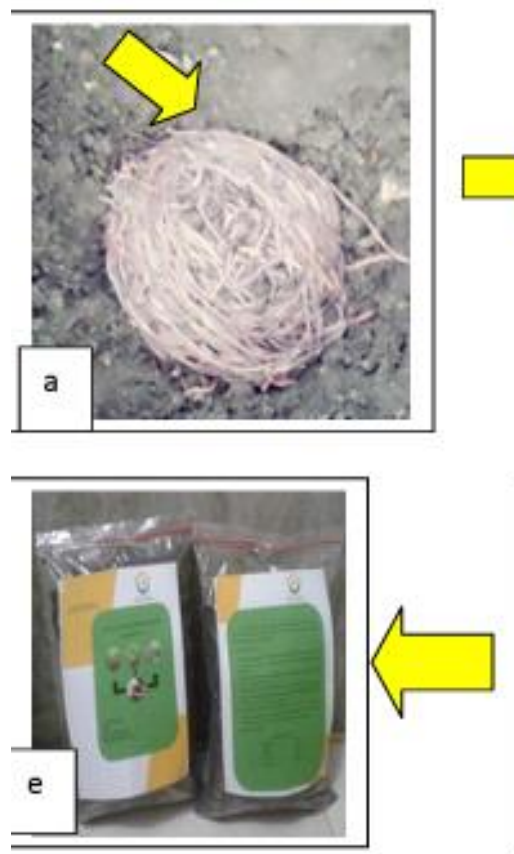
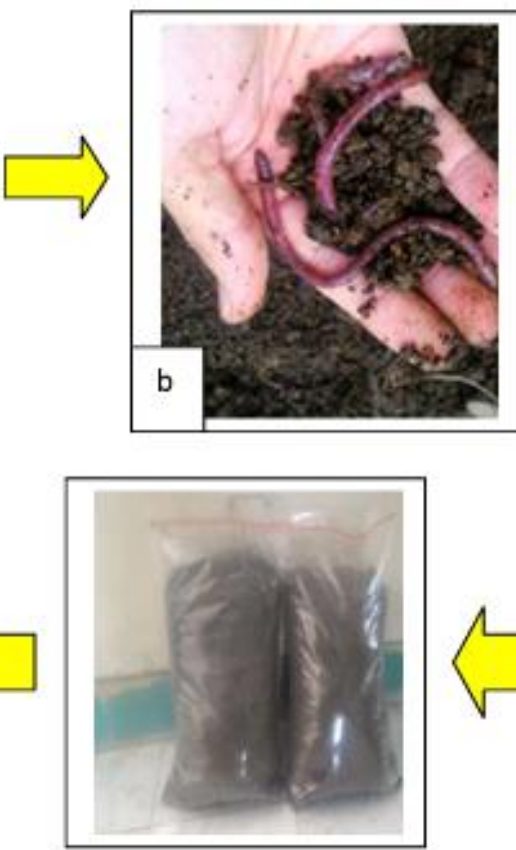
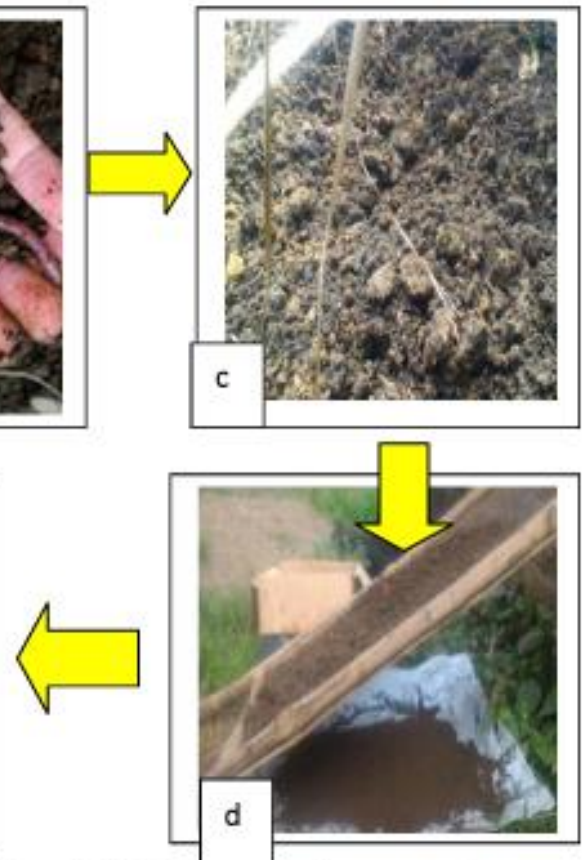

Jambar 1. Proses pembuatan pupuk kascing yang dimulai dari pengadaan cacing tanah (a), Lumricus rubellus (b), Pupuk kandang sapi yang telah matang yang telah ditebar cacing tanah (c), setelah terjadi proses dekomposisi menjadi pupuk kascing, diayak (d) dan produk yang siap dipasarkan yang telah diberi label (e) 


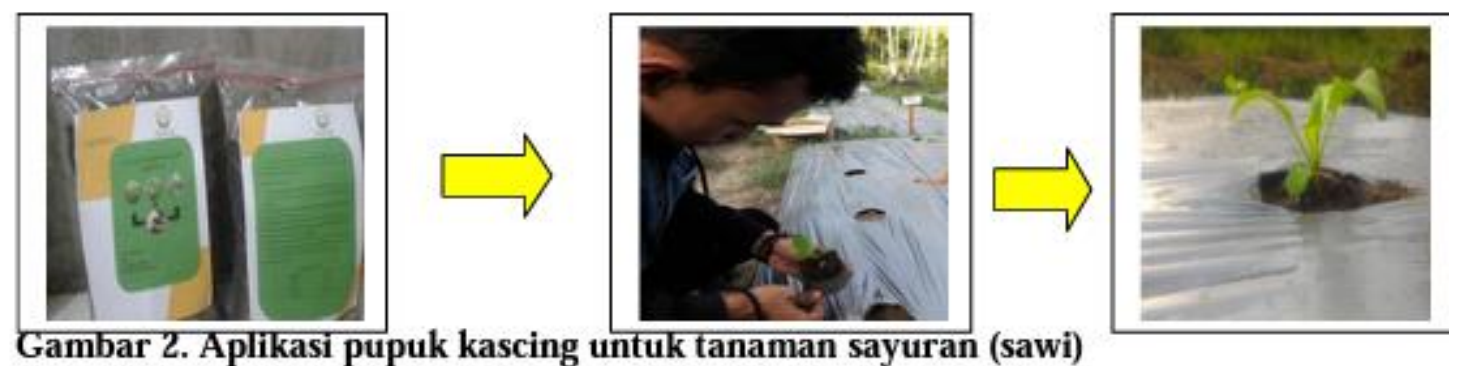

\section{PENUTUP}

Dari berbagai kegiatan yang telah dilakukan melalui program pengabdian Iptek bagi Masyarakat dapat diambil beberaa kesimpulan yaitu :

1. Penyuluhan tentang produksi Pupuk Organik bagi para petani dapat memberikan pengetahuan yang lebih luas tentang pertanian organik dan memberikan motivasi bagi mereka untuk membuka lapangan usaha dibidang pertanian khususnya produksi pupuk organik kascing.

2. Metode pelatihan dibidang produksi pupuk organik bagi para petani sayuran merupakan kegiatan yang memiliki kontribusi yang besar bagi pembangunan ekonomi masyarakat untuk lebih meningkatkan taraf kehidupan dan pendapatan bagi keluarga tani sehingga mampu menopang ekonomi keluarga yang kurang mampu.

3. Masyarakat tani di desa Paloh Punti, telah mempunyai motivasi yang kuat untuk berwirausaha khususnya di bidang pertanian, sehingga seyogyanya pemerintah dan pihak terkait dapat memfasilitasi, mendorong bagi tumbuhnya usaha baru yang berkelanjutan.

4. Perlu dikembangkan kerjasama yang cakupannya lebih luas antara perguruan tinggi dan pemerintah daerah untuk bersama-sama mengurangi angka pengangguran dan menumbuhkan wirausaha-wirausaha baru sesuai dengan potensi lokal.

\section{DAFTAR PUSTAKA}

Nurmawati,S dan Suhardianto, A. 2000. Studi Perbandingan Penggunaan Pupuk Kotoran Sapi dengan Pupuk Kascing Terhadap produksi tanaman selada. Laporan Penelitian, Fakultas Matematika dan Ilmu Pengetahuan Alam, Universitas Terbuka.

Kuruparan, $\mathrm{P}$ et al. 2005. Vermicomposting as an eco tool in sustainable solid wate management. Anna University. 
BAKTIMAS

Jurnal Pengabdian pada Masyarakat
Vol. 1, No. 2,

Agustus 2019
eISSN 2685-113x

pISSN 2685-0303

Maso, M.A. \& Blasi. A. B. 2008. "Evaluation of Composting as a strategy for managing organic wastes from a municipal market in Nicaragua", Bioresource Technology. Vol 99.

Prasetyo, A dan Putra, E. 2007. Produksi pupuk kascing (bekas cacing) dari limbah peternakan dan limbah pasar berbantuan cacing Lumbricus rubellus. Fakultas Teknik Universitas Diponegoro.

Simanungkalit et al, 2006. Organic Fertilizer and Biofertilizer. Balai Besar Litbang Sumberdaya Lahan Pertanian Badan Penelitian dan Pengembangan Pertanian.

Sayuti dan Fahri, 1999. Pedoman Praktis Budidaya Cacing Tanah (Bandung : Pusat Latihan Dan Pengembangan 